\title{
The belt and road initiative: domestic interests, bureaucratic politics and the EU-China relations
}

\author{
Jie Yu ${ }^{1}$ \\ Published online: 28 March 2018 \\ (C) The Author(s) 2018
}

\begin{abstract}
This article explores the linkages between domestic affairs and foreign policies in China in fulfilling its grand ambition of Belt and Road Initiative (BRI). It examines the complexities in decision-making process of "BRI" inside Beijing's administration. It departs from the most existing literature on BRI in Europe, which focus upon the geo-economic and geo-political impacts of the BRI. Instead, it adopts an "inside-out" approach by examining the actual policy process with a primary focus to individual actors such as the Party, the government department and the state-owned enterprises as well as individual academics. It also disentangles the intricate relations amongst the Party, the key decision-making institutions and the policy execution entities in determining the final outcome of the BRI. It will finally reflect the extent to which Beijing's bureaucratic complexities have impacted upon the EU and its member states' willingness in collaborating or in formally endorsing China's BRI.
\end{abstract}

\section{Introduction}

Since joining the WTO in 2001, around every 4 years, China has presented the world with a new concept, strategy or programme. These concepts are deeply rooted in the Chinese political system, but encapsulated in simple and memorable slogans. They have caused a great deal of both excitement and confusion abroad and within China. Past examples include 'peaceful rise', a 'harmonious world' and 'new great power relations'.

The latest arrival is the 'Belt and Road Initiative (BRI) ${ }^{1}$, commonly known as One Belt, One Road in public. No other policy in the world has launched as many global debates, with both serious doubts and some enthusiasm seen from academics,

${ }^{1}$ Commonly known as "One Belt, One Road" in the West, the author is using the official name given by the Chinese government-Belt and Road Initiative, in this article.

Jie Yu

j.yu7@1se.ac.uk

1 China Foresight, LSE IDEAS-the London School of Economics' Foreign Policy Think-Tank, London, UK 
policymakers and entrepreneurs. In May 2017, Beijing hosted the first ever 'Belt and Road Forum' in its usual lavish and choreographed style, attended by 29 head of states and delegates from 130 countries, to consolidate what China has achieved so far and to further promote the initiative (Xinhua 2017).

In September 2013, Chinese President Xi Jinping visited several Central Asian republics (Xi 2013). He reiterated China's intention of pursuing a policy of largescale investment. He emphasised the revival of the economic and cultural ties that once characterised China's relations with Eurasian countries during the past glory of the Silk Road, and promoted recreating the Silk Road Economic Belt in connection with the Maritime Silk Road. But despite the trade statistics, numerous conferences, tailored financial derivatives and new rail connections, defining the BRI is still difficult for the world outside China. It remains "longer on sweeping vision than on nuts-and-bolts practicalities" (De Jonquieres 2015).

Global analysts focus on the impact, positive or negative, of this ambitious undertaking while remaining vague about what BRI is and what aims China are pursuing through it. Few analysts understand who in Beijing decides on BRI projects and how the overall budget is distributed through the government.

A key reason for this tendency to overlook the complications of BRI and Chinese foreign policy decision-making in general is the assumption that China is a static and authoritarian state where policy is simply dictated from the top. This perception may have been valid under Mao, but is certainly no longer the case in contemporary China.

Another critical feature of BRI often ignored by pundits is the supremacy of domestic interests. This initiative is designed mostly to consume China's excessive industrial capacity, to secure its long-term energy supply and equally importantly to stabilise the troublesome Western borders of the Middle Kingdom that have been threatened by rampant home-grown Islamic jihadists.

This article explores the linkages between domestic affairs and foreign policies in China in fulfilling its grand ambition of BRI. In particular, it examines the complexities in decision-making process of "BRI" inside Beijing's administration. This contribution identifies and analyses a selected numbers of key stakeholders in shaping BRI. It also disentangles the intricate relations amongst the Party, the key decision-making institutions and the policy execution entities in determining the final outcome of the BRI. It will finally reflect the extent to which Beijing's bureaucratic complexities have impacted upon the EU and its member states' willingness in collaborating or in formally endorsing China's BRI.

It departs from the most existing literature on BRI in Europe, which focus upon the geo-economic and geo-political impacts of the BRI. Instead, it adopts an "inside-out" approach by examining the actual policy process with a primary focus to individual actors such as the Party, the government department and the state-owned enterprises as well as individual academics.

To a lesser extent, it also investigates the dynamics amongst the above-mentioned actors in shaping the policy agenda of the BRI. It utilises the Bureaucratic Politics Model (BPM) to interpret the policymaking and execution process. It argues that BPM could well widely apply to interpret the decision-making process of non-Western liberal democratic government. This piece combines discourse analysis of existing literature with primary semi-structured elite interviews to illuminate the decision-making process. Yet, given its limited space and very broad scope of the BRI, it is impossible to 
examine every single actor involved in the BRI. The author merely aims to provide some food for thought through a prism of Bureaucratic Politics.

\section{BRI: a container for China's domestic affairs?}

As argued earlier, too many pundits and policy practitioners in the West stress the geoeconomic and geo-political significances of BRI without paying attention to how domestic politics dictate the policies, budgetary distribution and detail of BRI. No discussion of major Chinese policy can ignore the ultimate aim of the Chinese Communist Party (CCP): staying in power and keeping absolute control. This requires stability and in turn requires the CCP keep its 'social contract' with ordinary Chinese people of growth and employment. BRI is no exception.

Against the backdrop of the Chinese economic slowdown and much discussed efforts economic rebalancing, China is searching for a new engine of economic growth. In particular, the government is looking for a way to reduce the regional economic development imbalance, one of the negative legacies left by Deng Xiaoping's landmark reforms. BRI has become key to this, connecting China's diverse regional development and revival programmes such Developing the Great West, Raising the Central Region and Revitalise The Old Northeast Industrial Bases. ${ }^{2}$

To this extent, one could argue that BRI is not a brand new initiative that was created by President $\mathrm{Xi}$ and his team overnight. Rather, it serves as a 'bag' or 'container' that virtually everything can be thrown into. Since the convening of the Central Financial and Economic Conference in December 2014, where the launch of the BRI initiative was officially decided, all 31 provincial level governments from Hainan to Hei Longjiang have scrambled to list their preferred projects and industries to be supported by BRI (Xinhua 2015). Some foreign pundits and even President Xi himself have commented on its lack of clarity (Xi 2016).

In a broader sense, BRI is seen as an essential element of China's further economic reform process itself. It was explicitly linked to the economic reforms of the Third Plenum of the 18th Party Congress, which focused on market allocation of resources with discussions indicating the senior leadership's thinking (Xi 2014). To this extent, BRI may also offer an 'upgraded' version of China's 'Go Global' strategy of making overseas investments, infrastructure building, and conducting mergers and acquisitions, mostly by the Chinese state-owned enterprises (SOEs). Chinese SOEs played a crucial role in the 'Go Global' strategy, but despite their advantage of sheer size, they remain short of global business exposure and corporate governance. The Chinese leadership intends to use BRI as an efficient vehicle to deepen its reforms to debt-laden SOEs and further their global footprint.

The BRI aspires to consume the excessive industrial capacity triggered by governmental intervention and underperforming Chinese companies. Ironically, it could also further exacerbate this longstanding symptom of the current economic structure established by Beijing. Regardless of the type of BRI project, participating companies

\footnotetext{
$\overline{{ }^{2} \text { A collection of different slogans }}$ and initiatives were advocated by the Chinese Communist Party and the Chinese government.
} 
are most likely to base their production model on the assumption of successful implementation of BRI.

However, the eventual success of delivering OBOR projects is not only dependent on China's financial resources and political capital but also equally importantly determined by the willingness of foreign partners. Both Beijing and Chinese participants must have a well thought out plan B to avoid waste in financial resources and manpower if some OBOR projects do not come to fruition.

\section{The bureaucratic politics and China's belt and road initiative}

The Bureaucratic Politics Model (BPM) is an actor-oriented approach that has been widely debated and utilised amongst IR academics (Alden and Aran 2011; Allison 1971; Freeman 1976; Halperin and Claap 1974; Halpern 1992; Hermann and Hermann 1989). Scholars often employ the BPM to analyse the foreign policies of liberal democracies. However, this article aims to challenge the prevalent view and to demonstrate that the BPM is by no means limited to a certain category of political system. It is possessed with great explanatory value when it is used to examine foreign policies regardless of the type of regime.

Chinese foreign policymaking is perhaps the world most complex decision-making process, due to the scope of issues, interaction between the Chinese Communist Party (CCP) and the Government, and diversity of interests and views. The launch and the management of BRI in the past 4 years have accurately reflected these intricacies.

The BPM is at its best to explain those intricacies despite BPM has emerged from a Western political science discourse. The BPM, according to Graham Allison, 'the government is neither a rational actor nor a conglomerate of loosely allied organisations, but many individuals representing different government departments participating in a competitive game' (Allison 1971).

The name of the game is politics where players in a certain position bargain via the established channels in a hierarchical government. By using BPM to interpret foreign policymaking process, the end result of foreign policy is neither a rational choice nor the outcome of an organisational process, rather the result of pulling and hauling and internal bargaining skills of different organs and their representatives.

This result depends on the respective power, position within the government and bargaining skills of different organs and their representatives. Top leaders decide on their stance towards and proposals for particular issues according to what is at stake for their particular department under specific conditions. In other words, as Allison and Freeman pointed out, "where you stand depends on where you sit" (Ibid; Freeman 1976).

Yet, there is a key difference between Western bureaucratic politics and the Chinese political system. The former occurs amongst various administrative government department whereas the latter intertwines between the Party and the Government. And when a policy dispute arises, a particular official or a government department's Party ranking holds a big sway. As what the Party Constitution states, "the Party commands the overall situation and coordinates the efforts of all quarters... and the Party must play the role as the core leadership among all other organizations at the corresponding levels" (CCP Constitution 2017).

As a result, final decision of foreign policymaking and other decision-making power concentrates in the hands of the CCP. This fits into what the Chinese Premier Zhou 
Enlai once proclaimed, "There is no small issue in diplomacy, all power belongs to the Central Committee" (Zhou 1990). ${ }^{3}$

The Party has an omnipresent role in every aspect of policymaking within the Chinese political system. Foreign policy and the advocacy of BRI are no exceptions. The seven members of the Standing Committee of the CCP Politburo (SCP) and the State Council generally set key the strategic guidelines, or long-term policy goals, of China's foreign affairs; however, more specific policy measures are mostly made and implemented by the various governmental ministries and state owned corporations. The making of the Chinese foreign policy has become an increasingly crowded playground for various equally powerful stakeholders competing for their departmental interests, like in any Western democracy.

China's foreign policy formulation has become increasingly pluralistic compared to the one of Mao's era. A process of decentralisation in decision-making has occurred since the 1978 Economic Reforms. As a result, there has been no single bureaucratic body that has supreme authority over the others when it comes to making certain decisions. Almost all bureaucracies and other players have utilised their resources and expertise to gain access to the highest level of Party elites in the search for more political clout and greater budgetary power.

Vested interest groups have played a significant part in the Chinese political system since 1978. As Graham Allison argued in his interpretation of the Cuban Missile crisis, whilst the rules of game might play out very differently in a democratic elected government, the fundamental characteristics of bureaucratic competition remain the same regardless of the type of government (Allison 1969; Halperin 1974).

One can argue that the BPM is largely applicable to liberal democracies with multiparty systems to satisfy the electorates' interests. Therefore, there are numerous interest groups across the whole political spectrum, which are making many attempts to shape the FP according to their desired outcomes. China, as an authoritarian state, is conventionally perceived as monolithic and therefore does not have interest groups which could oppose or influence decisions made by the Standing Committee of the Politburo (SCP).

However, the phenomenon of bureaucratic politics, described by Graham Allison and Morton Halperin has not restricted its application to a particular political system, and vested interest groups do play a significant part across through the Chinese political system.

The relevance of BPM to interpreting Chinese political system is twofold. Firstly, almost every domestic or external affairs decision made are based on a desire to achieve a consensus amongst the seven or nine members of the SCP, even if such consensus is sometimes merely an illusion. This consensus-seeking model has provided a unique opportunity to those potential interest groups seeking to influence the opinions of SCP members. Bargaining scenarios have often occurred in a process of consensus seeking amongst interest groups.

These interest groups maybe located both inside and outside of the formal FP making process. They mainly consist of governmental institutions, Chinese companies and even some foreign corporate organisations to a smaller extent. They attempt to formulate Chinese foreign policy based on their departmental preferences and corporate interests respectively. More importantly, none of current seven members of the SCP have much experience in foreign policymaking. This in turn has provided relevant

\footnotetext{
$\overline{{ }^{3} \text { Zhou Enlai's own words in } 1955}$
} 
Chinese foreign policy actors more channels and alternatives in which to shape Beijing's agenda.

Secondly, Chinese FP has increased in scope and content which has created fertile ground for the various stakeholders and interest groups to compete to shape the policy agenda via various channels.

Like implementation of any Chinese policy, the cornerstones are laid on the domestic front. Dramatic changes in the distribution of power and devolution of authority within Chinese bureaucracies have been happening since Deng Xiaoping's momentous economic reforms.

BRI is one of the best illustrations, perhaps the best, of institutional power distribution below the top Party Leadership.

Central ministries and provincial governments have scrambled to give BRI a meaning, gauge what it means for them and most importantly, how BRI could be used to get hold of or justify the use of project funds.

Many old 'China hands', such as Kenneth Lieberthal, Alice Miller and Elisabeth Economy, still dispute who makes Chinese foreign policy and why there are so many new institutions with obscure names proliferating across the Chinese foreign policy formation process (Lieberthal and Lampton 1992; Miller 2014; Economy 2014). The answers to these questions are far from clear. Neither China observers in the West nor the home-grown scholars in China have given satisfactory responses (Lu 1997; Zhang 2014).

The advocacy of BRI has also triggered the same confusion like the making of Beijing's foreign policy. It is suffering from a lack of policy and bureaucratic coordination. Xi's ambitious initiative raises two key questions for Beijing and its BRI partners and loan providers: Which departments or ministries carry the overall responsibility for BRI? What are the selection criteria for categorising infrastructure projects as parts of the initiative?

Besides setting broad policy priorities, the top leadership can determine the survival of any particular institutions. The Party can create a new bureaucratic framework, or assign and redistribute responsibilities and budgetary powers between existing agencies. However, such a restructuring process has not occurred on a regular basis.

What's more common are 'reshuffles' driven by issues and policy priorities. More often than not, an existing institution challenges the authority of any newly established organisation which may share competencies and budgetary powers. The Party will 'award' or 'punish' the challengers according to the situation and policy domains. This case has also largely applied to the pursuit of BRI.

According to the official document published in 2015, the lead organisation for coordinating efforts to pursue the initiative is the National Development and Reformation Commission (NDRC) with some shared responsibility from the Ministry of Commerce (MOFCOM) and Ministry of Foreign Affairs (NDRC 2015).

NDRC remains the most powerful institution in Beijing's central administration, probably the most powerful in China's macroeconomic policymaking in general. However, there is a key difference between the policy in the official document and practice in the corridors of power at the 'Court of Zhongnanhai'.

Using the normal CCP bureaucratic procedure, a 'Small Leading Group' has been set up for coming to key decisions on BRI. This group, consisting of the most senior policymakers and meeting monthly, is for tackling difficult and outstanding issues when disagreements arise and final judgments are required. 
The Small Leading Group for OBOR is based at the State Council and chaired by Zhang Gaoli, Standing Committee Member of the Party. Four deputy chairs share responsibilities equally:

- Wang Yang, the Deputy Premier in charge of Economic and Trade issues

- Wang Huning, Head of Policy Planning for the CCP and the so-called chief advisor for $\mathrm{Xi}^{4}$

- Yang Jiechi, the State Councillor for Foreign Affairs

- Yang Jing, the Secretary General for the State Council.

Looking at the chair and deputy chairs alongside the official policy paper, can we really say that the NDRC is leading the policy? It has no power to override the decisions of any of the five chairs. It has become 'sandwiched' between the Small Leading Group and the relevant central ministries. Each of the five chairs has their corresponding ministries to brief. It is almost impossible for the ministries to speak with one voice.

Apart from the above four mentioned ministries and Small Leading Group, there are other 15 different ministries and agencies that hold the lion's share of votes in the central government, influencing which projects are chosen to be part of OBOR.

It would be naive to assume that the Ministry of Finance and Ministry of Transportation have similar views while selecting high-speed railway projects across OBOR-related countries. The former looks for project with a solid return on investment, and the host country's potential financial risks and credibility for loans, whereas the latter looks for companies that can build high-speed railway tracks within the shortest period of time.

Nearly 32 provinces across China are also participating in ensuring their preferred projects being chosen. In doing so, each provincial government will receive a generous budgetary support in developing the chosen projects. Some provinces have begun to form alliances with certain central ministries to bid for project approvals, while other provincial governors and some CEOs of the State Owned Enterprises have taken to bypassing central ministries and communicating directly with the members of the Small Leading Group to gain their approvals.

A crucial reason why a selected number of provincial governors and CEOs of stateowned enterprise can bypass the central administration for project approvals is because they outrank some ministers within the Party. Even though in the hierarchy of the state they cannot influence ministers, their party seniority holds huge sway.

For example, the Minister of Transportation is not a member of Politburo and ranks No. 41 within the Central Committee of the CCP whereas the provincial governor of Chongqing $^{5}$ (an important Western Municipality) ranks No. 14 in the Central Committee and is a member of Politburo. In practical terms therefore, the governor of Chongqing can override the decisions made by a government minister in relation to OBOR.

This bureaucratic opaqueness and overarching policy-related uncertainty presents a major obstacle in China's efforts to convince the foreign partners to make a monetary or political investment in OBOR without providing an ultimate underwriter.

Deng described his ethos for reform in 1978 as "crossing rivers by feeling the stones" (Deng 1983). Xi has clearly adopted this approach in leading BRI. However, Deng used

\footnotetext{
${ }^{4}$ Both Wang Yang and Wang Huning elevated as standing committee members of the CCP in Octo 2017

${ }^{5}$ Please refer to the name list of 19 th CPC Central Committee
} 
this tactic when China was isolated in the immediate aftermath of the Cultural Revolution, whereas Xi needs the involvement of over 60 countries for his vision.

Beijing's lack of a clearly defined set of guidelines for the BRI development suits the Chinese pragmatic approach, which allows the Party and the government simply to shift plans during the implementation process whenever new opportunities arise. However, to fully engage with other stakeholders, China must invent a bureaucratic framework with reasonable consistency, setting up clear criteria for selecting potential projects that are credit worthy. This consistency must be spelt out loud and clear, and practiced diligently to reassure partners. Beijing is still at a very early stage of getting its house into good order on BRI, and Xi must tidy up quickly.

\section{BRI expertise shortage both in academia and state-owned enterprises}

As discussed earlier, this article focuses on each individual foreign policy actor within a BPM model. Both individual academics and Chinese state-owned enterprises should be treated as individual analytical unit when one assess the BRI from an "inside-out" approach.

Expertise providence has become a permanent feature of decision-making in Chinese foreign policy as well as a vehicle to influence the most senior leadership in power corridor in Beijing.

In particular, very few of the current members of the CCP Central Committee possesses a good understanding of geo-political and geo-economic complexities of countries which potentially participate in BRI, even if some of them are foreign affairs background or economists by training. They have always made decisions based on the knowledge of expert and academia. Such obsession with expertise has largely reflected some Chinese scholars 'works (Lu 1997; Zhang 2016).

However, an imminent challenge for BRI's success derives from inside China. China is not yet equipped with an extensive network of home-grown experts who have strong command of knowledge of the regions within the BRI framework.

According to the proposed BRI development plan, infrastructure investments and connectivity projects will run through more than 60 countries across Central Asia, Europe, West Africa, South Asia, and Southeast Asia. Apart from a large number of engineers, evaluating the viabilities of BRI projects requires geopolitical strategists who know the respective regions inside-out, it needs financial experts to understand the host countries' fiscal and monetary policies, and it needs demand project management teams having special knowledge of the local labour market.

However, at the moment, there are only a handful (less than 20) Central Asia and Middle East specialists inside China who are closely following the geopolitical situation within the two regions. ${ }^{6}$ Most of those experts have no direct access to the key government officials, influential academics, and business leaders of countries in Central Asia and the Middle East. Much of their existing research outputs are based on arbitrary collections of evidence rather than systematic analyses of the target countries.

Despite Chinese SOEs are determined to profit from Beijing's BRI and become some of the most important players in world economic affairs, however, their close

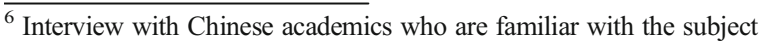


association and somewhat submissive relationship with the $\mathrm{CCP}$ and the Chinese government have impeded their overseas business plans.

Unlike Western multinational companies, the CCP and the government either at central or province level determine the Chinese SOEs' corporate strategies and investment plans under the BRI. Instead, each company's party secretary usually possesses final decisionmaking power to initiate corporate strategies. Given their direct ties to the government, it is difficult to judge whether SOEs' BRI investment plans are political decisions or based purely on commercial merit. Their close links with the state have become a double-edged sword for Chinese SOEs, not only providing financial support for potential BRI projects but also hindering growth and profit-making in foreign markets, where their direct links with Beijing have often provoked suspicions and hostility.

Most of the senior management teams of large Chinese SOEs who may potentially engage with BRI-related projects are appointed by the Party's Organisation Department $^{7}$ and equipped with industrial expertise, but not the necessary management skills and general market knowledge of the host countries. For example, they are usually unfamiliar with the market environments of host countries with little understanding of local labour union politics.

SOEs may hire leading global professional services firms to develop their potential OBOR projects. Some Chinese companies believe that outsourcing professional services firms is equivalent to possessing sound project management skills themselves and therefore readiness to pursue OBOR projects. Chinese companies utilise professional services firms mostly on the basis of their reputations rather than their specific knowhow. In part, this reflects the fact that engaging such major multinationals is often primarily a signal of their determination to pursue OBOR projects in line with central government objectives.

\section{The BRI relevance to the $\mathrm{EU}$ members state and the China-EU relations}

In an era when the Europeans seem incapable of resolving one severe crisis after another, Beijing will undoubtedly adjust its bilateral relations with the UK and reassess the value of its partnerships with other EU member states and Brussels. With respect to the emerging geo-political struggles in Asia, Europe remains disengaged. Nor has it shown any interest to get involved in the global power struggles between Beijing and Washington. Instead, China is seen almost exclusively in economic terms as an opportunity for European service-oriented economies and a threat to jobs in European manufacturing sectors. Thus, China's recent economic rebalancing has served as a major source of conflict between Beijing and Brussels.

Despite the multiple ongoing crises in Europe, China's EU policy still focuses on gaining access to the vast markets there in order to pursue its immediate economic activities, including its campaign of the BRI. Beijing also continues to flex its economic muscles and apply the well-practiced 'divide and rule' strategy in its dealings with EU member states regardless of their sizes. In particular, Beijing puts strong emphasis on courting Central and Eastern European countries with its ' $16+1$ ' cooperation

\footnotetext{
${ }^{7}$ An administrative department run by the CCP to appoint the most senior ministerial-level officials and CEOs of most important SOEs and state owned banks.
} 
framework, which has shown significant potential for generating a strong pro-China lobby within the EU (CEEC Summit 2017).

However, the European political elites must be aware that Beijing has devised several tactics to attain its economic diplomacy goals, which have also become more complex as a result of China's ongoing and much-needed efforts to transform the domestic economy. In particular, the ambitious 'Belt and Road Initiative/BRI' under the aegis of President Xi Jinping is confusing and creates ambiguities rather than incentives for EU member states to engage in further collaborations.

For instance, with a view towards revamping its EU policy agenda, Beijing has intertwined this initiative with domestic players, who, however, are little known to the European policymakers. This type of change in bureaucratic management will only exacerbate the already tenuous EU-China relations.

BRI causes a great deal of confusion for the EU member states and Brussels. Even a country like the UK, while it focuses upon post-Brexit relations with the EU, it also turns its eyes to play a greater role in participating in China's BRI ${ }^{8}$ (UK House of Commons, FA Ctte 2017). Beyond the trade statistics and new rail connections, the role of the BRI is not yet entirely clear for Europe.

Nevertheless, several EU member states have pledged their support for the initiative. Subsequently, in boasts picked up by the media and official papers, they spoke of their respective exclusive roles in the BRI initiative. There was talk of German and Polish railway connections, a historical route linking Venice to the ancient Silk Road, and even China's new plan to use the Piraeus port in Greece as the European receiving line of the twenty-first century Maritime Silk Road. There was also talk of the City of London setting up a RMB Internationalisation centre with an exclusive focus to the BRI infrastructure projects. ${ }^{9}$

Beijing's policy objective vis-à-vis the EU is representative of the fundamental characteristics of Chinese foreign policy. China is a country with 'dual identities', combining a developing country reality with the power ambitions of a great global power. This particularity has created 'issue-oriented national interests, which can easily conflict with the type of value-based relationship most preferred by the EU' (Zhang 2009:123). The dual-identity status influences Beijing's foreign policy in that it focuses on satisfying immediate economic needs rather than attaining long-term strategic goals. Despite the UK's vote to exit, China's issue-oriented foreign policy agenda will remain unchanged when it engages in the future with an independent UK and the EU.

China and the EU differ fundamentally in their manner of organising international affairs. The EU prefers that international politics be organised under a rule-based system, whereas China holds a Hobbesian view on power, which is all about absolute sovereignty, stability and control. It is therefore not surprising that Beijing's current EU policy has largely failed to overcome two of its biggest obstacles: obtaining market economy status (MES) and lifting the arms embargo. These two issues are as much about rules as well as about power. The strains show no sign of abating and illustrate that closer bilateral trade ties alone cannot achieve a political strategic partnership as both sides had originally hoped for.

\footnotetext{
${ }^{8}$ The author served as an expert witness to UK-China Trade Relations inquiry at the UK Commons Foreign Affairs Committee, 28th March 2017.

${ }^{9}$ Interview with City of London Asia Representative
} 
For many years, China's engagements with the EU have largely reflected its rapid economic growth as well as its rising international profile on global affairs. Decisionmakers in Beijing are very clear on what China wants from the EU: (1) free access to the European Single Market; (2) a secure home for its investments and, in particular, a willing partner for China's fast-growing acquisition of overseas assets; and (3) a meaningful diplomatic alternative to its increasingly fractious relationship with the US.

Meanwhile, China's rising international profile and relentless pursuits in its economic statecraft have further complicated its policy towards the EU at both levels of policymaking and policy implementation. The Union's timid response towards Beijing's grand ambition of BRI indicates well this lack of mutual trust and Europe's insufficient understanding of Beijing's foreign affairs practices. Without reforms and a changed mind-set on both sides, such policy-related complexities will continue to hamper China's relations with Brussels and the individual EU member states.

But despite these reasonable expressions of enthusiasm, the overall European response has remained reticent. Under the lens of bureaucratic politics, the ambitious initiative under the aegis of President Xi Jinping raises the following key questions that Beijing must answer to its potential partners: Which departments or ministries shall carry the overall responsibilities for BRI? And what are the selection criteria for categorising infrastructure projects as parts of the initiative?

Based on a conventional view from Europe, China is a unitary and centralised power renowned for its long-term strategic planning and rational foreign policy agenda. Under the current Chinese government structure, this picture lost its validity. Almost all institutions in the central leadership and local governments are involved in foreign relations to different degrees, and it is almost impossible for these ministries and agencies to see China's national interests the same way or to speak with one voice. This failure to streamline confuses not only outsiders but also the Chinese people themselves.

The EU and its member states should recognise that the scope and contents of Chinese foreign policies have expanded enormously since China joined the WTO. Certain policy domains, such as climate diplomacy, foreign aid and international financial governance, have only recently emerged as policy priorities for the CCP.

However, since the top leadership does not have enough expertise on its own or sufficient time to make the 'right' decision on the individual items of its expanded foreign policy agenda, those agencies and organisations that already possess strong expertise in relevant areas have become prominent and influential by means of providing expert advice and policy recommendations.

Besides traditional foreign policy actors, such as the Ministry of Foreign Affairs (MFA) and the Ministry of Commerce (MOFCOM), the new experts include institutions like the People's Bank of China and the National Reformation and Development Commission (NDRC).

These experts in the background act either semi-autonomously or autonomously. They have built up their own centre of gravity in their attempts to shape Beijing's EU policy agenda. On the international stage, they have become the de facto decisionmakers on behalf of the Party and the state. However, the flow of information derived from them creates a different set of problems for the Chinese government to carry forward a crucial initiative such as the BRI, as most of the new players have no vision of China's foreign affairs and therefore send confusing signals to the outside world.

The bureaucratic opaqueness and overarching policy-related uncertainties of the BRI present a major obstacle in China's efforts to convince the relevant European partners to 
make a monetary contribution to any infrastructure projects that would potentially mobilise their enormous financial resources without providing them with an ultimate underwriter to guarantee their investments.

For example, The EU-China Fund jointly established by European Investment Bank and the newly created Silk Road Fund has reflected this strong sense of reticence from the European side. ${ }^{10}$ The fund itself initially wished to be integrated into part of "Juncker Plan" (EIF 2017). Despite the political agreement between Beijing and Brussels, there has been little indication that EU-China Fund is ready to take off. ${ }^{11}$

Therefore, to engage with the EU on the BRI, China must actively promote a unified narrative of its vision and communicate the details of its plan on both a political and an entrepreneurial level. Beijing's lack of a clearly defined set of guidelines for the OBOR development suits the Chinese pragmatic approach, which allows the Party simply to shift plans during the implementation process whenever new opportunities arise. However, this approach generates ambiguities for Europeans, who are their targeted partners amongst other continents. Therefore, Beijing's lack of clarity regarding the OBOR initiative jeopardises any potential projects with the EU.

\section{Conclusion}

BRI is very much in line with the distinctive Chinese character of past grand initiatives. That is fluid in nature, opaque in implementation plan and flexible in concrete measures of projects. Such unique features are well understood and practiced by Chinese political elites in their corridor of power, yet frustrate foreign partners both at the governmental level and in entrepreneurial communities outside China.

China is in dire need of a sophisticated diplomacy and communication strategy in order to keep pace with its own newly acquired global power status. It needs new rhetoric that clearly spells out its coordinated foreign policy and the way it streamlines proliferations of bureaucratic actors involved in policymaking.

It is important for the Chinese leadership to not become too Sino-obsessed and to retain a keen interest in what others want, expect or fear from their interactions with China under the BRI framework. Like many other issues in China's foreign affairs, it should not be forgotten that BRI, whilst clearly dependent on Chinese objectives and actions, is also dependent on how others interpret these objectives and how they act on these interpretations.

Europe's political elite must remember that the people in charge of the BRI are groomed and trained within the system. It is therefore advisable to respect this continuity: the more the Europeans do today to engage the Chinese political elite in constructive debate on the initiative, the greater their chances are for future policies and the maturation of the BRI that will reflect European interests. The EU needs to devote more resources to understanding China and its ever-changing complex bureaucratic decision-making process, like China did with the EU at the beginning of Millennium. ${ }^{12}$

\footnotetext{
${ }^{10}$ Author's Interview with staff members at EIB and Silk Road Fund in Beijing, 2017.

${ }^{11}$ Confirmed by a senior journalist in Brussels and an official in Beijing

12 Author's interview with Zhou Hong, the former Director or European Institute, Chinese Academy of Social Science, Beijing, 2017
} 
Close scrutiny of the official BRI document published in 2015 reveals it to be largely an effort to advertise the BRI initiative. It suggests the proposed achievements of the initiative at the economic and strategic level, rather than referring any concrete methodology to achieve them. The document does not offer any time frame or deadline, and more importantly, does not suggest any business model to make the initiative work.

Sooner or later, the Chinese government must have concrete answers to fill in those conspicuous omissions if BRI is going to be a success. The 19th CCP Congress Political Report further stressed the centrality of BRI in relations towards China's foreign policy (CCP 2017). Yet, how much it can achieve is remain to be seen.

A central challenge to any future Chinese leadership will be how to develop a global foreign policy and respond to concerns in regions that are historically little known in China, but will affect and be affected by the country's economic growth. In order to improve its global diplomacy, China needs to draw on policies that go beyond the simple purposes of securing China's own economic interests. One hopes Beijing will learn this very quickly from its long march to the new Silk Road.

Open Access This article is distributed under the terms of the Creative Commons Attribution 4.0 International License (http://creativecommons.org/licenses/by/4.0/), which permits unrestricted use, distribution, and reproduction in any medium, provided you give appropriate credit to the original author(s) and the source, provide a link to the Creative Commons license, and indicate if changes were made.

\section{References}

Alden, C \& Aran, A (2011), Bureaucracies and foreign policy" from 'foreign policy analysis: new approaches New York: Routledge, pp 36-45

Allison TG (1969) Conceptual models and Cuban Missile Crisis. Am Polit Sci Rev 63(3):689-718

Allison TG (1971) Essence of decision: explaining the Cuban Missile Crisis. Little Brown, Boston, pp 20-23 CCP (2017), Full text of Xi Jinping's report at the $19^{\text {th }}$ CPC National Congress, $19^{\text {th }}$ October 2017, accessed at: http://www.chinadaily.com.cn/china/19thcpcnationalcongress/2017-11/04/content 34115212.htm

CCP Constitution (2017), "The constitution of the Communist Party of China", revised and adopted on 24 October, 2017, accessed at: http://www.xinhuanet.com/english/download/Constitution_of_the_ Communist_Party_of_China.pdf

CEEC Summit (2017), 'Li Keqiang Attends Sixth Summit of Heads of Government of China and Central and Eastern European Countries', 28 ${ }^{\text {th }}$ November 2017, accessed at: http://www.fmprc.gov.cn/mfa eng/topics_665678/lkqcxzgzdoldrhwfwxylcxsh/t1515311.shtml

De Jonquieres, G (2015), Grand plans will test Xi's mettle, Nikkei Asian Review, accessed at: http://asia.nikkei. com/Viewpoints/Viewpoints/Grand-plans-will-test-Xi-s-mettle?page=1, 7 Dec 2015

Deng X (1983) The selected works of Deng Xiaoping邓小平文献 (1975-1982). People's Publishing House, Beijing

Economy, E (2014), China's imperial president, Xi Jinping tightens his grip, Foreign Aff, Vol. 93, No.6, pp80-93

EIF (2017), EIB Group cooperation with China to be strengthened with new EUR 500 million Silk Road Fund equity investment initiative, accessed at: http://wwweif.org/what_we_do/equity/news/2017/eib_silk_road_ fund initiative.htm

Freeman, L (1976), Logic, politics and foreign policy processes: a critique of the bureaucratic politics model', Int Aff, Vol. 52, No.3

Halperin M, Claap P (1974) Bureaucratic politics and foreign policy. Brookings Institution Press, Washington D.C, p 23

Halpern, N (1992), "Information flows and policy coordination in the Chinese bureaucracy", from Lieberthal, K\& Lampton, D,eds, (1992), 'bureaucracy, Politics and Decision Making in Post-Mao China' Berkeley: University of California Press, pp125-148 
Hermann C, Hermann M (1989) Who makes foreign policy decisions and how: an empirical inquiry. Int Q 33(4):361-387

Lieberthal, K and Lampton, D,ed. (1992), Bureaucracy, politics, and decision-making in post Mao China Berkeley: University of California, Chapter 1, pp 1-30

Lu N (1997) The dynamics of foreign policy in China. Westview Press, Boulder, pp 121-124

Miller, A (2014), The trouble with factions, China's Leadership Monitor, No.44, pp3

NDRC (2015), Vision and Actions on Jointly Building Silk Road Economic Belt and 21st-Century Maritime Silk Road" by the National Reformation and development commission, March 2015, accessed at: http://en.ndrc.gov.cn/newsrelease/201503/t20150330 669367.html

UK House of Commons, Foreign Affairs Committee (2017), Transcript from inquiry into UK-China trade and economic relations, Accessed at: http://data.parliament.uk/writtenevidence/committeeevidence. svc/evidencedocument/foreign-affairs-committee/uk-relations-with-china/written/45751.html

Xi, Jinping (2013), Speech by Chinese president Xi Jinping to Indonesian parliament, October 2013, accessed at: http://www.asean-china-center.org/english/2013-10/03/c_133062675.htm

Xi, Jinping (2014), New Asian security concept for new progress in security cooperation, Remarks at CICA, May 2014, Shanghai, accessed at: http://www.fmprc.gov.cn/mfa_eng/zxxx_662805/t1159951.shtml

$\mathrm{Xi}$, Jinping (2016), “创造条件也要上的"一带一路" Paving the way to the belt and road initiative, FT Chinese, accessed at: http://m.ftchinese.com/story/001062389

Xinhua (2015), “深度解读一带一路, 各省怎样定位 Insight into one belt, one road, which province is doing what?", accessed at: http://news.xinhuanet.com/chanye/2015-04-01/c_1114833852.htm

Xinhua (2017), Belt and Road Forum, accessed at http://www.xinhuanet.com/english/special/201705 ydylforum/index.htm

Zhang T (2009) Sino-European relations: from the height to the width. In: Gaens B, Jakela J, Limnell E (eds) The role of the European Union in Asia. Ashgate, Farnham, pp 121-138

Zhang Q (2014) Towards an integrated theory of Chinese foreign policy: bringing leadership personality back in. J Contemp China 23(89):902-022

Zhang, Q (2016), Bureaucratic politics and Chinese foreign policy-making, 'J Int Polit', 2016, pp435-458

Zhou E (1990) Selected works of Zhou Enlai on Diplomacy. In: Beijing: the CPC central party literature office 